http://ahh.sagepub.com/

\title{
Not a dirty word: Arts entrepreneurship and higher education
}

\author{
Ruth Bridgstock
}

\begin{abstract}
While the majority of creative, performing, and literary artists are self-employed, relatively few tertiary arts schools attempt to develop capabilities for venture creation and management (and entrepreneurship more broadly) and still fewer do so effectively. This article asks why this is the case. It addresses underlying conceptual and philosophical issues encountered by arts educators, arguing that in all three senses of the term: new venture creation; career self-management; and being enterprising, entrepreneurship is essential to career success in the arts. However, the practice of entrepreneurship in the arts is significantly different from the practice of entrepreneurship in business, in terms of the artist's drivers and aims, as well as the nature of entrepreneurial opportunities, contexts and processes. These differences mean that entrepreneurship curricula cannot simply be imported from Business schools. This article also examines the arts-idiosyncratic challenge of negotiating distinctive and potentially conflicting entrepreneurial aims, using career identity theory. It concludes by suggesting strategies by which adaptive entrepreneurial artist identities can be developed through higher education programs.
\end{abstract}

Keywords: arts higher education, careers, entrepreneurship, employability, lifelong learning, identity, graduate attributes

In first world countries, visual, literary and performing artists are generally between three and five times more likely to be self-employed or working on a freelance basis than workers in other occupations (Bureau of Labour Statistics, 2011). In Australia, four in five professional artists maintain their own businesses (Throsby \& Zednik, 2010). In an era where the central task of higher education has become to prepare nascent professionals as far as possible for initial employment and future working lives beyond this (Boden \& Nedeva, 2010), one might expect that tertiary arts education institutions would have embraced entrepreneurship education - that is, education which is focused on the application, sharing, or distribution of art, as well as its creation or making. However, entrepreneurship continues to be a significant source of confusion and also controversy among arts educators and arts practitioners (Beckman, 2007; Hong \& Bridgstock, 2011). The inclusion of entrepreneurship in undergraduate arts courses remains inconsistent and surprisingly minimal (Hong, Essig \& Bridgstock, 2012), particularly given the influence of the creative industries policy agenda in the United Kingdom and Australia, which over the last decade has linked creative work with economic growth in advanced economies.

\section{THE CREATIVE INDUSTRIES AND THE ARTS}

The Creative Industries are defined as those activities which have their origin in individual creativity, skill and talent, and have the potential to create wealth and jobs through the generation and exploitation of intellectual property (Department for Culture Media and Sport 2008, p.3). As such, they include literary, visual and performing arts disciplines ('the arts'), with which this article is concerned, and also a range of other creative fields where significant intellectual property creation is undertaken, such as design, film, television, radio, advertising, games, publishing, and architecture.

The reason that these diverse fields have been clustered into the Creative Industries is that creativity and innovation are now considered to be key determinants economic growth in advanced nations (Department for Culture Media and Sport 2008; Cutler 2008). Wealth creation is dependent upon the capacity to continually make discoveries, innovate and invent new content. The STEM disciplines have long been recognised as key to innovation and therefore economic growth; creative industries policy similarly elevates creative fields as key sources of new content creation (Cutler, 2008; 
Department for Culture Media and Sport, 2008), and as synthesisers of innovation throughout the economy, and key contributers to the culturisation of all economic activity (Potts \& Cunningham, 2008).

The creative industries argument is borne out by national level economic data. Census analyses show that collectively, the creative industries are growing significantly faster than other economic sectors (Higgs, Cunningham \& Pagan, 2007; Higgs, Cunningham \& Bakhshi, 2008). However, recent reanalysis of Australian Census data (Cunningham, 2012) indicates that the greatest growth in the Creative Industries is actually occurring in creative services (business-to-business activities like design, architecture, software development and advertising), rather than in cultural production fields (the arts, film \& television, and publishing). The most significant employment growth for cultural production workers can be found outside the cultural production sectors, either 'embedded' in creative services industries, or working in a cultural production capacity outside the creative industries entirely (Cunningham, 2012).

In contrast with more traditionally configured industries such as finance, the creative industries are dominated by networked clusters of sole-traders, micro-businesses, and small-to-medium enterprises (Creigh-Tyte and Thomas 2001). These creative business networks constantly form and re-form value-chains to create new products and services. Creative professionals, including artists, are therefore often likely to be self-employed, and/or employed on a short-term contractual 'by project' basis, at least in part.

\section{ARTISTS’ CAREERS}

Artists' career patterns have received some research attention over the last decade, and there are now several published labour force survey-based descriptions of the distinctive nature of arts careers (e.g., Ball, Pollard, \& Stanley, 2010; Throsby \& Zednik, 2010). Most visual, performing and literary artists engage, at least to some extent, in portfolio careers (Bridgstock, 2005; Mallon, 1999). The portfolio career pattern comprises a continually evolving patchwork of grant-based (i.e., publicly subsidised) and/or commercial projects, jobs, and educational experiences. A portfolio of arts work may be supplemented by additional concurrent work activities - the ubiquitous 'day job' - in order to meet the artist’s financial obligations (Throsby \& Zednik, 2010).

In the main, artists' careers are individually constructed in an ongoing and unfolding way, often with minimal opportunity for either stable employment or progression as an employee within a firm. The onus is on the artist or designer to recurringly obtain or create employment and to manage their own career progression (Arthur, Inkson, \& Pringle, 1999). Throughout the arts, work is usually obtained via 'who you know' - that is, via informal social and professional contacts, and offers are made on the basis of the quality and success of previous work, rather than formal application and interview processes (Throsby and Zednik 2010).

A further highly distinctive feature of artists' careers is a blurring of the boundaries between work and personal life (Holden, 2007; Lange, Kalandides, Stober, \& Mieg, 2008). As discussed by Bennett (2009) and Bridgstock (2005), many artists can be appropriately described as protean careerists (Hall, 2004; Hall \& Chandler, 2005), because as well as individually constructing their own career paths, they also tend to possess strong personal motivations for building a career in arts. Their personal identities are often linked quite strongly with their arts practices (Brown, 2007), and they value psychological success and aspire to achievement of personally determined professional goals. The protean career pattern is characterised by: (1) personal construction of career and recurrent acquisition or creation of work (which likely to occur on a freelance or self-employment basis); and (2) strong intrinsic motivations for, and personal identification with, career (Hall, 2004).

It follows that the artist who is engaging in the protean career pattern should possess well developed arts entrepreneurship skills, as well as highly developed skills associated with arts practice, that is, creation or making of work. However, there remains significant confusion around exactly what entrepreneurship means with respect to arts education (see, for instance, Beckman, 2007). Broadly speaking, arts entrepreneurship skills are the skills associated with the application, sharing or 
distribution, as opposed to the generation or making, of art and creative work. However, as will be discussed in more depth later in this article, the usual sense of term entrepreneurship we have inherited from business disciplines as involving pursuit of profit and commercial gain (Bhide, Sahlman, Stancill, \& Rock, 1999) does not necessarily apply, and there are other important differences as well. For the artist, the practice of entrepreneurship is multi-layered, and qualitatively different from the practice of entrepreneurship in the traditional business sense, as will be argued in the next section of this article.

\section{ENTREPRENEURSHIP EDUCATION IN THE ARTS: CONCEPTUAL ISSUES}

The core strength of arts education has always been the development of high level disciplinary creative and technical skills, often through an intensive and rigorous studio experience (e.g., Don, Garvey, \& Sadeghpour, 2008). Arts entrepreneurship - the development of skills associated with application, sharing, and distribution of creative work - have tended to occupy a significantly less important position in arts programs. Partly, this imbalance reflects strong traditions in arts education curricula and pedagogic practice. However, it also reflects a state of confusion among educators about what arts entrepreneurship education is, and what skill sets it should involve (see, for instance, Beckman, 2007; Hong, Essig, \& Bridgstock, 2011)

Beckman (2007) reviewed arts entrepreneurship higher education throughout the United States, and delineated two streams of definitional and curricular thought among arts educators with respect to entrepreneurship education: entrepreneurship as 'new venture creation' (involving enterprise start-up and management), and what Beckman calls the 'transitioning' approach, which corresponds broadly to Schumpeterian and Druckerian (Dees, 1998; Drucker, 1985; Schumpeter, 1934) notions of entrepreneurship as 'being enterprising' (that is, opportunity recognition or creation, and adding value of some kind). The present article will also discuss a third sense to arts entrepreneurship: career selfmanagement and being employable. There is of course significant overlap between the three senses for instance, in order to be employable and creatively fulfilled (career self-management), an artist may find they need to set up a business (new venture creation), which meets a certain market need and adds a certain type of cultural value (being enterprising). Each of these senses will be defined and discussed briefly in the next section, commencing with new venture creation.

\section{ARTS ENTREPRENEURSHIP AS NEW VENTURE CREATION}

The 'new venture creation' sense of arts entrepreneurship is a more traditional view which corresponds the most closely to Business School notions of entrepreneurship. It was also the most common definition given by arts educators in Beckman's (2007) review. Under the new venture creation approach to arts entrepreneurship education, students learn skills and knowledge associated with starting and growing an artistic enterprise, including sales and marketing, legal issues, business strategy, and finance (Consortium for Entrepreneurship Education, 2004). New venture creation skills specific to the arts may include grantsmanship and operating within a subsidized, or partly subsidised and partly commercial context, intellectual property issues for creative enterprises, and cultural stakeholder management.

The majority of professional artists maintain their own enterprises, and thus it seems clear that emerging artists will require a basic grounding in new venture creation and management skills for the arts. However, when Bridgstock conducted case studies of outstandingly successful artists and designers (Bridgstock, Dawson, \& Hearn, 2011), she found that many of the study participants did not have a natural propensity toward engaging in the 'nuts and bolts' of running an enterprise. Rather, these participants possessed an awareness of, and an understanding of, core business concepts, and had formed successful partnerships and professional relationships with individuals who were more business-minded than they were. Thus, it seems likely that business fundamentals, arts sectoralspecific knowledge, and social networking capability (Bridgstock, Dawson \& Hearn, 2011), are probably examples of core arts entrepreneurship curriculum elements, but specialist business topics like taxation law or accrual accounting may not be. 
Arts entrepreneurship programs that focus on less tangible capabilities such as opportunity recognition, entrepreneurial behavior, or resilience, are emphasising the 'being enterprising' sense of arts entrepreneurship. The 'being enterprising' sense of arts entrepreneurship education is concerned with the identification or creation of artistic opportunities, and exploitation of those opportunities in terms of applying or sharing artistic activity in order to add value of some kind.

Numerous lists of attributes for successful enterprise can be located in the general business literature, and some of these may have applicability to arts entrepreneurship as well. These lists tend to emphasise enterprising qualities (such as 'vision', or 'proactiveness') or broad meta-theoretical constructs involving multiple cognitive, affective, and behavioural processes. For instance, Duening's (2010) 'Five Minds for the Entrepreneurial Future' presents a very broad theoretical framework of generic capabilities for success in enterprise. Duening's enterprising 'minds' are: (1) The Opportunity Recognising Mind; (2) The Designing Mind; (3) The Risk Managing Mind; (4) The Resilient Mind; and (5) The Effectuating Mind.

First, the Opportunity Recognising Mind identifies distinctive patterns in the artist's context (such as consumer behaviour, collaborator availability, or resources) as creating an opportunity. The Designing Mind then moves to exploit that opportunity, by creating a new artistic product or service; or redesigning a product or service to meet that opportunity. The Risk Managing Mind minimises risk in the venture, through internal (adaptation) strategies, or external (management) strategies like diversifying investors. The Resilient Mind is responsible for emotional, financial, and reputational rebounding from failure. Finally, the Effectuating Mind undertakes focussed and goal-directed action, to ensure that the venture becomes reality.

However, as with the skills required for new venture creation, the act of being enterprising in the arts probably involves a somewhat different set of capabilities to being enterprising in business. Not only are the contextual patterns the Opportunity Recognising Mind must identify likely to be quite idiosyncratic to the arts, the strategies the Designing and Effectuating Minds must employ to bring artistic enterprises to fruition are also likely to be unique. This is because the arts are distinctive in terms of factors like its markets and the nature of demand for products and services, value chains, labour processes, regulatory mechanisms, and product/service diversity (Caves, 2000). Also, the act of being enterprising in the arts involves responses to both contextual drivers (such as potential market demand for artistic work) and strong intrinsic 'protean career' motivations (an internal desire to create something aesthetic, motivated by a sense of personal achievement (Henry, 2007).

\section{ARTS ENTREPRENEURSHIP AS EMPLOYABILITY AND CAREER SELF-MANAGEMENT}

The third sense of arts entrepreneurship relates to employability, that is, the artist's ability to build a sustainable career through recurrently obtaining or creating arts employment, and the skills relating to career self-management. Career management is the ability to manage intentionally the interaction of work, learning and other aspects of life throughout the lifespan (Haines, Scott, \& Lincoln, 2003; Watts, 2006). It occurs through an ongoing interaction of reflective, evaluative and decision making processes, based on ongoing information gathering about one's own needs, and the requirements of industry and the world of work in the arts (Bridgstock, 2009). Effective career self-management in the arts can involve a significant degree of adaptability and self-reinvention. It also relies upon procedural skill sets that deFillippi and Arthur (1994) refer to as 'knowing how' and 'knowing who(m)' knowing the sector-specific rules of the game when it comes to finding or making work, and networking / building relationships for employability.

It makes sense that artists, who engage in portfolio careers and who must therefore continually obtain or create employment, would benefit from having well developed career management skills. This is in strong contrast with the majority of the workforce, who are more likely to engage in a traditional career pattern involving an ongoing employment relationship with one employer, and whose career paths are often largely predetermined. In empirical support of the importance of career selfmanagement to the career in arts, Bridgstock (2011) conducted a study of several hundred emerging and established artists, and other creative workers who engage in portfolio careers (such as designers 
and film makers), in which she demonstrated a link between the propensity and ability to career selfmanage and positive subjective and objective dimensions of career success.

It can be seen that professional artists need to be entrepreneurial in all three senses of the term. The onus is on the individual artist to create their own career, which will often involve a portfolio of work at least partly conducted through self-employment and freelance work. Further, this work will always involve adding value of some kind, through identifying or creating, and then taking advantage of, creative opportunities. However, it can also be seen that entrepreneurship in the arts has characteristics which distinguish it from entrepreneurship in other sectors, including contextual and sectoral features, the nature and processes of artistic work, the kinds of value that artistic work can add, and the motivations of the artist. Entrepreneurs in other fields are often 'pulled' to becoming entrepreneurial, driven by the challenge of starting a new venture or developing a new product. By contrast, artists are often 'pushed' to entrepreneurship through necessity, and often have minimal natural inclination towards business ownership or commercial endeavours (Richards, 2005). Put simply, artists tend to want to make art and make a living from it - business entrepreneurs tend want to run a successful enterprise. The next section of this paper discusses some of these distinctions between arts entrepreneurship and business entrepreneurship in more detail.

\section{ENTREPRENEURSHIP EDUCATION IN THE ARTS: PHILOSOPHICAL ISSUES}

Entrepreneurship education in the arts is a controversial topic. The term 'entrepreneurship' is often associated with a strong and overriding commercial and profiteering imperative, an association which comes from the traditional business entrepreneurship literature (e.g., Timmons \& Spinelli, 2003). This emphasis on commercial entrepreneurship has also been taken up by some creative industries and creative economy theorists. For instance, in the seminal work 'The Creative Economy', Howkins (2002) states that successful creative entrepreneneurs must, "realize their success will be measured in financial terms; the rest is in shadows" (p.130). Many arts educators, arts students and practicing artists, find this prevailing commercial emphasis incongruent with their career values and therefore objectionable (Beckman, 2007).

When discussing entrepreneurship with artists, the notion l'art pour l'art (art for art's sake) often arises. L'art pour l'art is a slogan of Bohemian culture (Eikhof \& Haunschild, 2006) and the Romantic era. It means that artistic pursuits require no justification or instrumental purpose (Becker 1982, Caves 2000). L'art pour l'art is a statement about art having intrinsic value without any additional moral, didactic, or utilitarian function. The phrase was initially used by Victor Cousin in a lecture "Truth, Beauty, Goodness" delivered at the Sorbonne in 1854. Cousin stated: "We must have religion for religion's sake, morality for morality's sake, as with art for art's sake...the beautiful cannot be the way to what is useful, or to what is good, or to what is holy; it leads only to itself” (Davies, Higgins, \& Hopkins, 2009, p.129).

However, when artists are asked about their motivations for making art, they give a variety of answers, some of which do indeed imply instrumental reasons for practice at least some of the time. The artistic protean career, with its emphasis on personal motivations for career and psychological success, does seem to involve intrinsic motivations such as artistic fulfillment and growth, creation of beauty, engaging in challenge and creating something entirely new. However, just as often (and often at the same time), artists report extrinsic motivations such as connection and communication with others; building community; recognition from colleagues and career furtherment; contribution to the growth and development of their artforms; and making living (Bridgstock, 2007). Of course there are also some artists who are strongly motivated by profit. For instance, Warhol (1975) famously stated, "making money is art and working is art and good business is the best art".

The point is that arts practice is highly individual and can be associated with many different, and even multiple concurrent, motivations and aims. However, all professional artists desire to share their work with others in some way, and to add value of some kind or kinds. While money will inevitably be part of the equation in arts entrepreneurship, it needn't be the fundamental driver. As Beckman (2007) argues: "even when art is commercial in nature, it does not need to involve compromising artistic 
objectives... arts entrepreneurship education programs should ideally be built upon a foundational shift in thinking from "money ruins art” to "money enables art.”” (p.103).

A parallel argument can be found in the business literature with respect to the burgeoning discipline of social entrepreneurship, with which arts entrepreneurship would seem to have something in common. Dees (1998) differentiates social entrepreneurs from business entrepreneurs by saying that business entrepreneurs use wealth creation is a way of measuring value creation, but that making money is just a means to an end for social entrepreneurs. The next section of this article draws upon the social entrepreneurship and triple/quadruple bottom line business literature (Mair \& Marti, 2006) to discuss multiple bottom line entrepreneurship among artists.

\section{NEGOTIATING MULTIPLE BOTTOM LINES}

The idea that all entrepreneurs, whatever their discipline or sector, must balance multiple aims and purposes, is one whose time may finally have come. Chell (2007) points out that traditional definitions of entrepreneurship from the Business School (e.g., Bhide, et al., 1999) tend to neglect to mention the social and personal outcomes and benefits of entrepreneurship - such as belongingness, community, friendship, and development of one's capability. She concludes that even within forprofit businesses there must be a balancing of social and economic behaviour that creates social and economic value. Indeed, numerous entrepreneurship theorists in the business literature are now pointing out the fact that many ventures demonstrate a range of goals and outcomes, and that there may well be tensions between these goals and outcomes which the entrepreneur must negotiate (Neck, Brush, \& Allen, 2009).

Triple bottom line theory (TBL) captures an expanded spectrum of values and criteria for measuring venture success. Developed by Elkington (1998), the theory emerged out of the corporate social responsibility literature, and recognises that the value enterprises can add is much more than commercial. Triple bottom line theory moves from the position that environmental sustainability and social well-being are just as important as commercial goals, and must be factored in to any business' bottom line. With the ratification of the United Nations and ICLEI TBL standard for urban and community accounting in early 2007, TBL became the prevailing approach to public sector full cost accounting.

Hawkes (2001) augments triple bottom line theory with a fourth bottom line: that of culture. Culture can be defined as the 'way of life' of different groups of people through the expression of their identities, belief systems, aspirations, values, dress, language, food and all aspects of their existence (Hawkes 2001). Hawkes (2001) argues that cultural vitality is just as important to society as social equity, environmental responsibility and economic viability.

While designed to enhance the accountability of commercial enterprises and public programs - and also to highlight tensions between, and facilitate integration (blending - Emerson, 2003) of social and economic values, multiple bottom line theory also has applicability in making visible the bottom line aims of artistic enterprises and arts entrepreneurs. Eikhof and Haunschild (2006; see also Menger, 1999) argue that artists have to juggle and/or blend two identities: their identity as an artist, which provides them with work motivation and creative momentum, and their identity as a small business, which enables them to make a living. While this statement acknowledges the well-documented tension between artistic motivations and commercial ones, it reflects insufficiently the range of aims possible in artistic enterprise (as discussed under 'Philosophical Issues' above); the potential conflicts and complementarities between these aims; and the juggling act in which many artists engage in order to achieve their protean (that is, personally determined) professional goals.

Juggling and blending multiple entrepreneurial bottom lines is central to arts entrepreneurship, and to building sustainable arts careers (Caves, 2000; Eikhof \& Haunschild, 2007; Menger, 1999). Knowing how to practice in a personally value-congruent way, in order to add value of some type/s through art, is a fundamental aspect of successful arts practice, and yet the process of learning how to do this is often tacit and the outcomes implicit and not easily explained, even by successful professional artists. The ability to tap into and pursue personal career goals, whilst also being able to chase other shorter 
term venture creation, project, and enterprise goals successfully, involves both career identity depth, and career identity adaptability, on the part of the artist.

\section{THE ENTREPRENEURIAL IDENTITIES OF ARTISTS}

Successful arts entrepreneurship commences with entrepreneurship in the career self-management sense of the term. Initially, the process is concerned with the development of a strong and adaptable career identity, which in turn influences the subsequent career-related actions of the artist. Career identity is the individual's definition of themselves as it relates to work and career, reflecting motivations, personal meanings, and individual values (Meijers, 1998). It answers questions such as 'who I am', 'who I want to be' and 'what's important to me' in career. It has an enormously strong effect on career-related behaviour, acting as a 'cognitive compass' (Fugate, Kinicki, \& Ashforth, 2004, p.17) that directs and sustains the artist's learning and career-related actions.

Career identity develops through experiences, and also through changing needs and desires through the lifespan (Watson, 2008). Individuals often maintain multiple and shifting identities which can be complementary or conflict (Kreiner, Hollensbe, \& Sheep, 2006). However, adaptive career identities are those which are based in good information about the self and the world of work. They are relatively immutable in terms of the artist's core values and career needs, and at the same time are flexible in other ways, to ensure that the artist is open to identifying or creating rewarding career opportunities which may otherwise be hidden to them. Adaptive career identities must address entrepreneurship as well as creation/making - namely, how the artist intends to apply or share their work.

The artist's career identity determines the enterprise opportunities the artist will seek and recognize, and the types of new ventures that they will create. The constitution of enterprises, their environments and behavior, and therefore the skill sets required, can be quite different depending on the bottom line drivers of a venture, and it is advantageous for the artist to know early on which types of aims they would prefer to pursue.

Some degree of identity incongruence is inevitable, as the artist needs to engage in the contrasting activities of creative/making and enterprising/venturing, and multiple venturous aims. Gotsi et al (2010) identify two key strategies for juggling multiple conflicting identities: differentiation, and integration. Differentiation is concerned with adopting different roles in different phases of work that is, alternating sequentially between the identities (Ashforth \& Mael, 1989). The second identity strategy observed by Gotsi et al (2010) is identity integration, or formation of a 'meta-identity'. This method involves developing a higher level identity which subsumes the sub-identities (Pratt \& Foreman, 2000). Contradictions can be reconciled by emphasizing the synergies between the subidentities. In Gotsi et al's (2010) study, artists in a product design firm came to view themselves as 'practical artists', which incorporated aspects of both artistic identity and business identity. The artists were able to resolve their potential identity conflicts by thinking of their roles as inclusive of a number of complementary creative and business-related activities. As practical artists, they could pursue both business and artistic aims concurrently, and find complementarities between those aims.

\section{DEVELOPING ENTREPRENEURIAL ARTIST IDENTITIES THROUGH HIGHER EDUCATION}

So far, this article has argued that entrepreneurship, in several senses of the term, is an integral part of artists' professional lives, and the development of an adaptive entrepreneurial identity is, in turn, a fundamental element of entrepreneurship. However, as previously discussed, qualitatively different fundamental drivers pertain to arts entrepreneurship and business entrepreneurship (along with other differences already documented in this article), and therefore long-established business school approaches to teaching entrepreneurship and the development of an entrepreneurial identity may have limited applicability to the arts without significant modification. So what can schools of art do to help develop capable artist entrepreneurs?

The iterative and reflective process of adaptive career identity building can begin in the first year of tertiary study, alongside the development of foundational disciplinary and technical skills and knowledge (Bridgstock \& Hearn, 2011). In this first year, students should be supported through a 
highly scaffolded process of research into, and reflection upon, their core career interests, abilities and values, coupled with learning about/experiencing various aspects of their intended professions and the labour market, ideally in authentic industry settings and facilitated by industry professionals (Bridgstock, 2011). During this career identity building phase, students consider questions such as: what drew me to this course? What are my core work values and how can the range of career options open to me fit with those values? What value am I going to add through my work? How will I know it is worthwhile? Not only are students given the chance to develop an adaptive career identity through this process, including exploring career opportunities they had not yet considered and refining their ideas about work and careers, but they are also encouraged to learn the high level skills associated with whole-of-career development and to continue the process for themselves in an ongoing way (Bridgstock, 2011).

The second phase of development of the entrepreneurial artist identity involves learning to identify value-congruent opportunities for enterprise (whether commercial, cultural, social, or a mixture of these), and how to create ventures or projects to pursue these opportunities. A case study approach may be useful here. Students should be exposed to multiple types of arts ventures representing a range of venture aims, in order to understand the different ways they can be set up, the opportunities that they exploit and the value that they add, the contexts in which they operate, and the resources they draw upon. During this phase, it is highly worthwhile to have students explore the career and venture motivations of professional artist cases, and the ways those professional artists have negotiated multiple bottom lines and identity tensions in their careers.

The third phase of entrepreneurial artist identity development involves experiential, project-based work, in which the student learns by 'doing' entrepreneurship (Raffo, Lovatt, Banks, \& O’Connor, 2000) in a community of practice with other students, mentors and academic staff (Brown, 2007). Students co-create and pursue their own projects in alignment with identified opportunities and their own values, and various facilitators (teaching staff, senior students/ recent graduates and industry professionals) provide support and feedback. The processes involved in identifying opportunities to add value through art, and the identity negotiations are made explicit. This experiential work serves to further develop the adaptive career identity (Ashforth \& Johnson, 2001), as well as embedding core entrepreneurial skills and knowledge in an authentic way. Thus, students can make 'mistakes' in the safe environment of the university where there are relatively few repercussions of venture failure, and then analyse and learn from their entrepreneurial experiences in class, thus acquiring entrepreneurial self-confidence and opportunity identification skills, both argued to be important to creative enterprise success (Fillis, 2006). This is a powerful student-centred approach to the development of the entrepreneurial identity, and arts entrepreneurship skills.

\section{CONCLUSION}

This article has argued for the importance of arts entrepreneurship in three specific senses as part of the suite of capabilities needed by professional artists. Further, it has argued for the development of arts entrepreneurship capabilities through higher education, and suggested concrete ways in which this might be achieved through the curriculum.

The previous discussion of the importance of application and sharing of artistic work in this article is meant in no way to imply that entrepreneurship capability development should supplant the development of the disciplinary capabilities which make artists effective practitioners, or indeed other important 'generic' capabilities (Barrie \& Prosser, 2004) they should develop, such as interpersonal skills, creative thinking, and problem-solving. Rather, entrepreneurship (as with other generic skills) must be woven into the fabric of the disciplinary curriculum, thus providing needed context, career relevance and links with the learner's extant knowledge - all essential for the active process of knowledge construction. As Carey and Naudin (2006) observed, entrepreneurship education must be embedded 'from day one' of a course, and must focus on developing and stimulating an enterprising culture and way of thinking. Entrepreneurship is not a sub-topic within a business-related curriculum, but is a complex set of qualities, beliefs, attitudes and skills that underpin all areas of working life. 
In choosing to embrace entrepreneurship capability development in students of art, school leaders must not neglect the professional development and support of teaching staff.

Professional development for arts entrepreneurship education should affirm existing effective teaching practices, reinforce the importance of disciplinary content, and address philosophical, conceptual, and logistical concerns. It may be beneficial for teaching staff themselves to engage in a scaffolded process of career and entrepreneurial identity development and refinement.

During this process, staff can be supported to reflect upon and celebrate the ways that they add value, envision new directions for their work, and invigorate their arts and education practices.

Word count: 6872 words 


\section{REFERENCES}

Arthur, M., Inkson, D., \& Pringle, J. (1999) The new careers: Individual action and economic change. London: Sage.

Ashforth, B. E., \& Johnson, S. A. (2001) 'Which hat to wear? The relative salience of multiple identities in organizational contexts', in M. A. Hogg \& D. J. Terry (eds) Social identity processes in organizational contexts, pp. 31-48. Philadelphia: Psychology Press.

Ashforth, B. E., \& Mael, F. (1989) 'Social identity theory and the organization'. Academy of Management Review 14(1): 20-39.

Ball, L., Pollard, E., \& Stanley, N. (2010) 'Creative Graduates, Creative Futures'. London: Report for Council for Higher Education in Art and Design.

Barrie, S., \& Prosser, M. (2004) 'Generic graduate attributes: Citizens for an uncertain future.'. Higher Education Research \& Development 23(3): 243-246.

Beckman, G. (2007) '"Adventuring" arts entrepreneurship curricula in higher education: An examination of present efforts, obstacles, and best practices'. The Journal of Arts Management, Law, and Society 37(2): 87-112.

Bennett, D. (2009) 'Academy and the Real World'. Arts and Humanities in Higher Education 8(3): 309-327.

Bhide, A., Sahlman, W., Stancill, J., \& Rock, A. (1999) Harvard Business Review on Entrepreneurship. Boston: Harvard Business Press.

Boden, R., \& Nedeva, M. (2010) 'Employing Discourse: Universities and Graduate "Employability"'. Journal of Education Policy 25(1): 18.

Bridgstock, R. (2005) 'Australian artists, starving and well-nourished: What can we learn from the prototypical protean career?'. Australian Journal of Career Development 14(3): 40-48.

Bridgstock, R. (2007) 'Success in the protean career: A predictive study of professional artists and tertiary arts graduates'. Unpublished Doctoral Dissertation, Queensland University of Technology, Brisbane, Australia.

Bridgstock, R. (2009) 'The graduate attributes we've overlooked: Enhancing graduate employability through career management skills'. Higher Education Research and Development 28(1): 2739.

Bridgstock, R. (2011) 'Skills for Creative Industries graduate success'. Education \& Training Vol. 53(1): 9-26.

Bridgstock, R., Dawson, S., \& Hearn, G. (2011) 'Cultivating innovation through social relationships: A qualitative study of outstanding Australian innovators in science, technology, and the creative industries', in A. Mesquita (ed.), Technology for creativity and innovation: Tools, techniques and applications: IGI-Global.

Bridgstock, R., \& Hearn, G. (2011) 'A conceptual model of capability learning for the 21st century Knowledge Economy', in D. Rooney, G. Hearn \& A. Ninan (eds) Handbook on the Knowledge Economy. Cheltenham: Edward Elgar.

Brown, R. (2007) 'Promoting entrepreneurship in arts education', in C. Henry (ed) Entrepreneurship in the Creative Industries: An International Perspective .Cheltenham: Edward Elgar.

Bureau of Labour Statistics (2011) 'Occupational Outlook Handbook, 2010-11 Edition: Artists and Related Workers', Available at http://www.bls.gov/oco/ocos092.htm (accessed October 5, 2011).

Carey, C., \& Naudin, A. (2006). Enterprise curriculum for creative industries students: An exploration of current attitudes and issues. Education+Training 48(7): 518-531.

Caves, R. E. (2000) Creative industries: Contracts between art and commerce. Cambridge: Harvard University Press.

Chell, E. (2007) 'Social enterprise and entrepreneurship: Towards a convergent theory of the entrepreneurial process'. International Small Business Journal 25(1): 5-26. 
Consortium for Entrepreneurship Education (2004) 'National Content Standards for Entrepreneurship Education', Available at http://www.entreed.org/Standards Toolkit/index.htm (accessed May 2, 2011).

Creigh-Tyte, A., \& Thomas, B. (2001). 'Employment'. In S. Selwood (Ed.), The UK cultural sector: Profile and policy issues. London: Policy Studies Institute.

Cunningham, S. (2012). Hidden innovation: Policy, industry and the creative sector. St Lucia: University of Queensland Press.

Cutler, T. (2008) 'Venturous Australia - Building Strength in Innovation. Report on the Review of the National Innovation System.' Canberra: Australian Government.

Davies, S., Higgins, K. M., \& Hopkins, R. (2009) A companion to aesthetics (2nd ed.). Chicester: WileyBlackwell.

Dees, J. G. (1998) 'The meaning of social entrepreneurship. Comments and suggestions contributed from the Social Entrepreneurship Founders Working Group.', Available at http://faculty.fuqua.duke.edu/centers/case/files/dees-SE.pdf (accessed July 21, 2011).

deFillippi, R., \& Arthur, M. (1994) 'The boundaryless career: A competency-based perspective.'. Journal of Organizational Behavior 15: 307-324.

Department for Culture Media and Sport. (2008) 'Creative Britain: New talents for the new economy.' London: Department for Culture Media and Sport.

Don, G., Garvey, C., \& Sadeghpour, M. (2008) 'Signature Pedagogies in Music Theory and Performance', in R. Gurung, N. Chick \& A. Haynie (eds) Exploring Signature Pedagogies: Approaches to Teaching Disciplinary Habits of Mind, pp. 81-98. Sterling, VA: Stylus.

Drucker, P. F. (1985) Innovation and entrepreneurship. New York: Harper and Row.

Duening, T. (2010) 'Five minds for the entrepreneurial future: Cognitive skills as the intellectual foundation for next generation entrepreneurship curricula'. Journal of Entrepreneurship 19(1): 1-22.

Eikhof, D., \& Haunschild, A. (2006) 'Lifestyle meets market: Bohemian entrepreneurs in creative industries'. Creativity and Innovation Management 15(3): 234-241.

Eikhof, D., \& Haunschild, A. (2007) 'For art's sake! Artistic and economic logics in creative production'. Journal of Organizational Behavior 28(5): 523-538.

Elkington, J. (1998) 'Partnerships from cannibals with forks: The triple bottom line of 21st century business'. Environmental Quality Management 8(1): 37-51.

Emerson, J. (2003) 'The Blended Value Proposition: Integrating Social and Financial Results'. California Management Review 45(4): 35-51.

Fugate, M., Kinicki, A. J., \& Ashforth, B. E. (2004) 'Employability: A psycho-social construct, its dimensions, and applications'. Journal of Vocational Behavior 65(1): 14-38.

Fillis, I. (2006). Art for art's sake or art for business sake: an exploration of artistic product orientation. The Marketing Review, 6(1): 29-40.

Gotsi, M., Andriopoulos, C., Lewis, M. W., \& Ingram, A. E. (2010) 'Managing creatives: Paradoxical approaches to identity regulation'. Human Relations 63(6): 781.

Haines, K., Scott, K., \& Lincoln, R. (2003) 'Australian Blueprint for Career Development', Available at http://www.dest.gov.au/directory/publications/australian blueprint.pdf (accessed October 20, 2010).

Hall, D. (2004) 'The protean career: A quarter-century journey'. Journal of Vocational Behaviour 65(1): 1-13.

Hall, D., \& Chandler, D. (2005) 'Psychological success: When the career is a calling'. Journal of Organizational Behavior 26(2): 155-176.

Hawkes, J. (2001) The fourth pillar of sustainability: Culture's essential role in public planning. Melbourne: Common Ground.

Henry, C. (2007) Entrepreneurship in the creative industries: An international perspective. Cheltenham: Edward Elgar Publishing.

Higgs, P. L.,Cunningham, S \& Bakhshi, H. (2008) 'Beyond the Creative Industries: Mapping the 
Creative Economy in the United Kingdom.' London: NESTA.

Higgs, P. L., Cunningham, S \& Pagan, J. (2007) 'Australia's Creative Economy: Basic Evidence on Size, Growth, Income and Employment.' Brisbane: ARC Centre of Excellence in Creative Industries and Innovation.

Holden, J. (2007) 'Publicly-funded culture and the creative industries'. London: Demos \& Arts Council England.

Hong, C., \& Bridgstock, R. (2011) 'Educating the enterprising artist and the arts entrepreneur: Staff, student and graduate perceptions and experiences of enterprise and entrepreneurship education in the Creative Industries'. Brisbane: Queensland University of Technology.

Hong, C., Essig, L., \& Bridgstock, R. (2011) 'The enterprising artist and the arts entrepreneur: Emergent pedagogies for new disciplinary habits of mind.', N. Chick, A. Haynie \& R. Gurung, (eds) Exploring Signature Pedagogies: Approaches to Teaching Disciplinary Habits of Mind Sterling, VA: Stylus.

Howkins, J. (2002) The creative economy: How people make money from ideas. London: Penguin.

Kreiner, G. E., Hollensbe, E. C., \& Sheep, M. L. (2006) 'Where is the" me" among the" we"? Identity work and the search for optimal balance'. The Academy of Management Journal 49(5): 10311057.

Lange, B., Kalandides, A., Stober, B., \& Mieg, H. (2008) 'Berlin's Creative Industries: Governing Creativity?'. Industry \& Innovation 15(5): 531-548.

Mair, J., \& Marti, I. (2006) 'Social entrepreneurship research: A source of explanation, prediction, and delight'. Journal of world business 41(1): 36-44.

Mallon, M. (1999) 'Going "portfolio": Making sense of changing careers'. Career Development International 4(7): 358-369.

Meijers, F. (1998) 'The development of a career identity'. International Journal for the Advancement of Counselling 20(3): 191-207.

Menger, P. M. (1999) 'Artistic labour markets and careers'. Annual Review of Sociology 25: 541-574.

Neck, H., Brush, C., \& Allen, E. (2009) 'The landscape of social entrepreneurship'. Business Horizons 52(1): 13-19.

Potts, J, \& Cunningham, S. (2008) 'Four models of the Creative Industries'. International Journal of Cultural Policy 14(3): 233-47.

Pratt, M. G., \& Foreman, P. O. (2000) 'Classifying managerial responses to multiple organizational identities'. Academy of Management Review: 18-42.

Raffo, C., Lovatt, A., Banks, M., \& O'Connor, J. (2000) 'Teaching and learning entrepreneurship for micro and small businesses in the cultural industries sector'. Education+ Training 42(6): 356365.

Richards, G. (2005) 'Developing entrepreneurship in the creative industries: The role of higher and further education'. London: Department for Culture Media and Sport.

Schumpeter, J. (1934) The theory of economic development. Cambridge, MA: Harvard University Press.

Throsby, D., \& Zednik, A. (2010) 'Do you really expect to get paid? An economic study of professional artists in Australia'. Melbourne: Australia Council for the Arts.

Timmons, J., \& Spinelli, S. (2003) New Venture Creation: Entrepreneurship for the 21st Century: Irwin/McGraw-Hill.

Warhol, A. (1975) The philosophy of Andy Warhol: From A to B and back again. San Diego: Harcourt Brace.

Watson, T. J. (2008) 'Managing identity: Identity work, personal predicaments and structural circumstances'. Organization 15(1): 121-143.

Watts, A. G. (2006) 'Career development learning and employability' Learning and Employability Series Two, Available at http://www.heacademy.ac.uk/learningandemployability.htm (accessed June 25, 2012). 